\title{
Research of Innovation and Entrepreneurship Education in Colleges and Universities in the Era of Knowledge Economy
}

\author{
Wang Xiaobin \\ School of Economy and Management \\ Shenyang Aerospace University \\ Shenyang City, China
}

\begin{abstract}
In the new era, the importance of knowledge can be imagined, and in order to face challenged brought by the era of knowledge economy, special requirements are proposed to colleges and universities. First of all, colleges and universities should have a clear goal in education and pay attention to cultivating innovative talents. Second, they need to change their education philosophy to cultivate new types of talents that can meet demands of this era of economy. Therefore, colleges and universities need to make clear of the connotation of innovation and entrepreneurship education to constantly make innovations combined with new educational philosophy while emphasizing some problems in education to constantly make reforms and innovation as well as enhance the establishment of teaching staffs. This paper discusses how colleges and universities should provide innovation and entrepreneurship education in the era of knowledge economy so as to promote the cultivation of talents in China.
\end{abstract}

Keywords-Era of knowledge economy; Higher education; Innovation and entrepreneurship education; Educational philosophy; Research and analysis

\section{INTRODUCTION}

The era of knowledge economy is an era based on knowledge. In such a society, knowledge is wealth, and only equipped with knowledge can we stand out in the fierce competition. At present, China advocates the transference from the economic model to the knowledge economic model so only core knowledge is the key for the development of enterprises and even the country, and innovation and entrepreneurship education is the main means to cope with the era of knowledge economy. In this regard, China still lags behind developed countries. However, with the increasing importance of knowledge, China is increasing its input in innovation and entrepreneurship education. Therefore, researching innovation and entrepreneurship education plays a rather important for the development of the country.

\section{ANALYSIS OF INNOVATION AND}

ENTREPRENEURSHIP EDUCATION'S CONNOTATION

First of all, we need to make clear that innovation and entrepreneurship education is not the synthesis of innovation education and entrepreneurship education, but the combination of these two: to cultivate the innovative ability of talents according to the common goals of the two so as to meet the demands of social development. Innovation and entrepreneurship education realizes the sublimation of innovation education and entrepreneurship education in both concepts and contents. This education pays attention to cultivate students' innovation awareness and capacity so as to make students adapt to the society and make great contributions in the fierce market competition using their knowledge so as to establish their own businesses. This education could motivate a person's potentials and cultivate students' personality and characters, which is more conducive to cultivate all-round talents compared with simple innovation education and entrepreneurship education.

About the core connotation of innovation education, we explain it as the education given to all the students at school while combining the concept of innovation education and entrepreneurship education so as to cultivate new type of innovative talents. Innovation and entrepreneurship education is an important measured to cope with the era of knowledge economy and a significant development strategy of China with immeasurable value both from the perspective of national education and economic development.

\section{ANALYSIS OF STATUS QUO OF INNOVATION AND ENTREPRENEURSHIP EDUCATION IN COLLEGES AND UNIVERSITIES}

A. Some Colleges and Universities do not pay Enough Attention to Education without Correct Educational Philosophy

Innovation and entrepreneurship education is to teach students how to their own when the boss, and teachers believe that the proportion of success is very low, is not a good way to develop students after graduation, will be the main focus of education, professional education as a focus, will be mainly focused on imparting knowledge, so the implementation of innovative education is not enough, so that the implementation of innovative education in Colleges and universities is very worrying, this misunderstanding will seriously affect students' innovative consciousness and innovative ability, this misunderstanding will seriously affect students' innovative 
consciousness and innovative ability, this misunderstanding will seriously affect students' innovative consciousness and innovative ability. The traditional education idea already can not meet the needs of the society to the talented person, therefore said, the idea is and the society matches, only then can better adapt to the social development, not to be eliminated by the society. The innovation and entrepreneurship education as the edge of the school education is related to the leadership and teacher's serious mistakes, so it must be corrected, otherwise it will affect the development of the personnel and the national economy.

\section{B. Insufficient Teaching Reform}

Influenced by traditional ideas, innovation and entrepreneurship education can not be integrated into the various professional talents training plan, from another point of view is that the current education reform is not deep enough, and there is no change in the course of the school curriculum and teaching model. In curriculum arrangement, the innovation and entrepreneurship education curriculum, mostly in the form of elective courses, students are not very high, students are difficult to learn the knowledge, in the teaching content arrangement, only to teach some of the theory of entrepreneurship and very old business case, and the current social derailment, and the relationship between students, not to let students form a coherent knowledge context; in teaching mode, the traditional teaching mode, the innovation is not enough. Whether curriculum arrangement, curriculum content and teaching mode, they are not conducive to the smooth development of innovation and entrepreneurship education, functions in the edge of the struggle.

\section{Teaching Staffs cannot meet the Demands}

Innovation and entrepreneurship education in Colleges and universities lack a complete teaching theory and teaching system, the relevant teachers do not have adequate teaching experience, it is difficult to achieve good teaching results. For teachers, should have a strong ability to innovate, to entrepreneurship have sufficient understanding, it is best to have a certain entrepreneurial experience, so in teaching in order to better the knowledge innovation and entrepreneurship education continues to teach, let students learn more things, but most teachers did not this kind of ability and experience, so that in the teaching process more is textbook case, not real will teach students with innovation and entrepreneurship in the knowledge, is just empty talk, no experience, not the students convinced.

\section{Few Achievements in Research of Education}

In spite of China's strong advocacy of entrepreneurship, driven by employment, employment, employment pressure, but the current social environment for college students entrepreneurship is full of difficulties, there is a great risk and problems, while college students entrepreneurship, whether it is social or family, are not widely recognized, support is not high. Because of the success of College Students' entrepreneurial success, the research of innovation and entrepreneurship in China is also less, so it is very important for the further development of education.

The cultivation target of innovation and entrepreneurship education is the college students, this group has a very strong plasticity, with professional knowledge and passion of fighting spirit, can be referred to as a special group, in the process of entrepreneurship has certain advantages. There are many needs to improve, from the point of view of education, educational philosophy, curriculum setting, teachers, and other aspects of the problem, and the results are mostly based on the theoretical analysis, the lack of a real business practice, students' innovation and entrepreneurship is less, so that the contradiction between innovation and entrepreneurship is more intense.

\section{IMPORTANCE OF INNOVATION AND ENTREPRENEURSHIP EDUCATION}

In terms of the current era of economy, it can be said that innovation and entrepreneurship education is an indispensable requirement for China to cope with challenge and realize the development of national economy, thus it is of great significance. In the era of knowledge economy, although the various countries in the political and economic culture and other aspects of the difference, but the degree of emphasis on knowledge is the same, the personnel training as an important national strategic decision-making, innovation and entrepreneurship education, training of high-quality personnel as an important goal of education.

China from the 17th National Congress of the Communist Party of China and the national strategy for strengthening the country and the talent to strengthen the strategy, technology, education, talent, as an important force for national development, enhance our country's independent innovation ability is an important measure of national development, in the future economic development, technology, education, talent will become more and more important role. Only with the ability of innovation and Entrepreneurship Talent in the era of rapid development of science and technology transformation, seize the fundamental and technological innovation, which have their own intellectual property rights of the core, this will let countries more competitive, so as not to be controlled by others in the fierce international competition. In the final analysis, the competition of science and technology is the competition of talents. The innovation talents are the main training objectives of innovation and entrepreneurship education.

Compared with the developed countries, China's innovation and entrepreneurship education started late, so in the core intellectual property, let us recognize its importance, which restricts the development of our economy, with the arrival of the era of knowledge economy, its importance can be imagined, we must increase the intensity of innovation and entrepreneurship education, reform education mode, cultivate outstanding innovative talents, so as to promote the development of China's economy and international status.

\section{ENDEAVOR TO DEVELOP INNOVATION AND ENTREPRENEURSHIP EDUCATION}

\section{A. Colleges and Universities Need to Change} Traditional Educational Philosophy

At present, the education concept is still based on the traditional teaching of knowledge, and the school is the function of the dissemination of knowledge with the lack 
of cultivating students' innovation ability. This education mode is not conducive to the current demand for talent training. Under the current background, colleges and universities should the importance of clear innovation and entrepreneurship education, seize the opportunity to adapt to the reform and innovation, continue to develop new ideas and changes in personnel training mode, educational workers in Colleges and universities to will deepen the education as important means, pay attention to the quality of personnel training, to be aware of the profound connotation of the innovation and entrepreneurship education, the new teaching method, in the arrangement of the curriculum and the content arrangement strengthen of innovation education and enterprise education efforts, innovative thinking to integrate the education mode to and will continue to cultivate students' innovation ability.

\section{B. Enhance Teaching Staff Construction in Colleges and Universities}

Strengthen the construction of teaching staff is mainly reflected in two aspects, the first aspect is all kinds of professional teachers, economic management is a compulsory course, only to have a full understanding of economic management in order to allow enterprises to better inventory, while the legal profession is also a very close bond, these teachers combine innovative entrepreneurship education philosophy to open a special course, and try to choose the business experience of teachers in the classroom, if there is no such a teacher, then select a part of the enterprise work experience. The second aspect is the invitation of successful entrepreneurs to make a speech, this model is to provide students with a chance to close contact with successful people, so that the success of the personal experience to explain to the students to listen to the students to promote their understanding of the business. The combination of this kind of University and industry can not only avoid the disadvantages of the teachers' lack of practical experience, but also make the entrepreneur drive students to measure entrepreneurial enthusiasm. The school sends the specialized teacher to go to the enterprise to carry on the specialized training, lets the teacher have certain practical experience to the innovation talented person's raise to have the very important influence.

\section{Create Campus Environment of Innovation and Entrepreneurship}

A good campus culture environment can make innovation and entrepreneurship education to achieve a very good development, and get rid from the edge of education, continue to penetrate into the school teaching plan. In the process of cultural construction, we can use radio, newspapers and Internet media to make students realize the importance of innovation, so as to enhance its value, and to make students participate actively in the activities, make students participate in the practice, and make students participate in the practice, so that students can improve their ability in their activities and produce a sense of pride.

\section{CONCLUSION}

Education plays an important role in the background of knowledge economy because the quality of education could determine the quality of a country's future talents and is associated with the future destiny of the country. China has already realized the importance of innovation and entrepreneurship education in cultivating talents. Shouldering the important mission, colleges and universities need to give full play to education and be courageous to accept the challenge. Aiming at problems in current higher education, they need to reform education timely so as to promote the development of innovation and entrepreneurship education, enhance the strength of talents and occupy a favorable position in the fierce international competition.

\section{REFERENCES}

[1] Wang You. On the Educational Philosophy of Innovation and Entrepreneurship Education in China's Colleges and Universities [J]. Guangdong Social Science, 2013,01:112-117.

[2] Zeng Zhen, Liu Meng. Analysis of Status Quo of Innovation and Entrepreneurship Education for College Students and Research into Countermeasures $[\mathrm{J}]$. Northern Economy and Trade, 2013,01:110+115.

[3] An Jianqiang. Research of Innovation and Entrepreneurship Education in Colleges and Universities in the Era of Knowledge Economy [J]. Education and Career, 2013,14:84-85.

[4] Lin Xiaoyan. Analysis of Improving Effectiveness of Innovation and Entrepreneurship Education for College Students in the New Era [J]. Educational Theory, 2015,13:141-142.

[5]Zuo Tao. Research of Innovation and Entrepreneurship Education for College Students under the Background of Knowledge Economy [J]. Journal of Science and Education (the second half), 2015,06:12-13.

[6] Ji Haimiao. Exploration of Entrepreneurship Education in Chinese Colleges and Universities [J]. Journal of Chongqing University of Science and Technology (social science edition), 2011,08:161-162.

[7] Zhou Shuqin. Research into Innovation and Entrepreneurship Education for College Students [J]. Monthly of Scientific and Technological Entrepreneurship, 2011,12:23-24+27.

[8] Fang Mingzhi. Promoting Innovation and Entrepreneurship Education in Colleges and Universities should Emphasizing on Improving College Graduates' Innovative and Entrepreneur Ability [J]. Small-and-Medium-Sized Enterprise Management and Science and Technology (the first half), 2011,10:253-254.

[9] Zhou Bing. Research into the Prospect of Innovation and Entrepreneurship Education in Colleges and Universities [J]. Research into Higher Education in Heilongjiang, 2014,10:128-130.

[10] Zhi Zhiguo. On Entrepreneurship Education for College Students [J]. New West (Theoretical edition), 2012,04:122+126.

[11] Jiang Erlan. Analysis of Establishing Entrepreneurship Educational System for College Students [J]. Employment of China's College Students, 2012,18:55-59.

[12] Ning Zhong, Li Peiwen. Literature Review of Researches into Entrepreneurship Education in Colleges and Universities [J]. Education and Teaching Forum, 2012,39:255-257.

[13] Li Renjie, Shang Wanjun. On Connotation and Meaning of Innovation and Entrepreneurship Education for College Students [J]. Guide of Scientific and Technological Innovation, 2010,09:245.

[14] Sun Gang. Research into Establishing Innovation and Entrepreneurship Educational Mechanism for College Students [J]. Prospect of Science and Technology, 2015,20:274-275. 